\title{
A Review on Plant Tissue Culture, A Technique for Propagation and Conservation of Endangered Plant Species
}

\author{
Ojo Michael Oseni ${ }^{1,2} *$, Veena Pande $^{1}$ and Tapan Kumar Nailwal ${ }^{1}$ \\ ${ }^{1}$ Department of Biotechnology, Kumaun University, Nainital, \\ Bhimtal Campus, Bhimtal-263136, India \\ ${ }^{2}$ Department of Botany, Obafemi Awolowo University, Ile-Ife, Nigeria \\ *Corresponding author
}

\section{A B S T R A C T}

Keywords

Plant tissue culture,

Propagation,

Conservation,

Endangered plant

Article Info

Accepted:

26 June 2018

Available Online:

10 July 2018
Plant tissue culture has been widely employed in area of agriculture, horticulture, forestry and plant breeding. It is an applied biotechnology used for mass propagation, virus elimination, secondary metabolite production and in-vitro cloning of plants. Recently, plant tissue culture has been used for the conservation of endangered plant species through short and medium term conservation also known as slow growth and cryopreservation also known as long term conservation. These methods had been successfully used to conserve plant species with recalcitrant seeds or dormant seeds and showed greater advantage over the conventional methods of conservation.

\section{Introduction}

Conservation of natural resources is the wise use of the earth's resources by humanity. Usher (2000) defined conservation as the maintenance of genetic, species, and ecosystem diversity in the natural abundance in which they occur. Thomas (2003) sees conservation as the sacrifice of immediate rewards in return for delayed ones. As the global human population approaches eight billion, there is growing concern about the rate of extinction of other species that inhabit our planet (Barnosky et al., 2011; Dirzo et al., 2014). Compelling evidence points to humans as the direct or indirect cause of most modern extinctions. The primary threats to these species include residential and commercial development; overexploitation via fishing, hunting, or collecting; disturbance by humans during work and recreational activities; pollution; and the introduction of exotic species (Venter et al., 2006; Prugh et al., 2010; McCune et al., 2013).

The two main methods of conserving biodiversity are: ex-situ and in-situ conservation. Ex-situ conservation is the process of protecting or preserving an endangered species of either plants or animal 
outside of its natural habitat either by removing whole or part of that population from the threatened habitat and placing it in a new environment which may be a wild area or within human control environment. Methods of ex-situ conservation are Biological Gardens, Seed bank, Gene bank, Germplasm bank and In-vitro storage. While in-situ conservation involves the conservation and preservation of species in their natural habitat in places where the species naturally occurs. Under this method the entire ecosystem is protected and maintained so that all the constituent species, both known and unknown are conserved. The main methods of in-situ conservations are: Strict nature reserve (SNR), Games Reserve and National Park. In-situ conservation has been made almost impossible due to the disappearance of large wild areas as a result of natural disasters, pests, pathogens and threats from changing government policies and urban development. Ex-situ Conservation is very difficult to carry out due to the following problems: an adequate sample has to be taken for the conservation of genetic diversity, land space requirement is very important, particularly in the case of forest trees which are very large, whereas land availability drastically decreases, labour costs and trained personnel (Engelman, 1991).

Plant tissue culture is a modern method of propagation and conservation of plant species. Apart from their use as a tool of research, plant tissue culture techniques have in recent years, become of major industrial importance in the area of plant propagation, disease elimination, plant improvement and production of secondary metabolites. Small pieces of tissue (named explants) can be used to produce hundreds and thousands of plants in a continuous process. A single explant can be multiplied into several thousand plants in relatively short time period and space under controlled conditions, irrespective of the season and weather on a year round basis (Akin-Idowu et al., 2009).
In-vitro organ culture offers an alternative source for the conservation of endangered genotypes (Sengar et al., 2010), which can be achieved using slow growth (short and medium term conservation) procedure or cryopreservation (long-term conservation) (Scherwinski-Pereira et al., 2010). Tissue culture protocols can be used for preservation of plant tissues or organ when the targets for conservation are clones instead of seeds. This helps to keep the genetic background of a crop and to avoid the loss of the conserved patrimony due to natural disasters, whether biotic or abiotic stress (Tyagi et al., 2007). The plant species which do not produce seeds (sterile plants) or which have 'recalcitrant' seeds that cannot be stored for long period of time can successfully be conserved via in-vitro techniques for the maintenance of gene banks. The method also reduced storage space for maintaining a large number of explants in an aseptic environment, the stored materials are readily available for use and it can be easily seen to be alive.

\section{Plant tissue culture}

Plant tissue culture is the in vitro aseptic culture of cells, tissues, organs or whole plant under controlled nutritional and environmental conditions (Thorpe, 2007) often to produce the clones of plants. The resultant clones are trueto type of the selected genotype. The controlled conditions provide the culture an environment conducive for their growth and multiplication. These conditions include proper supply of nutrients, $\mathrm{pH}$ medium, adequate temperature and proper gaseous and liquid environment. Plant tissue culture technology is being widely used for large scale plant multiplication. Apart from their use as a tool of research, plant tissue culture techniques have in recent years, become of major industrial importance in the area of plant propagation, disease elimination, plant improvement and production of secondary metabolites. Small pieces of tissue (named 
explants) can be used to produce hundreds and thousands of plants in a continuous process. A single explant can be multiplied into several thousand plants in relatively short time period and space under controlled conditions, irrespective of the season and weather on a year round basis (Akin-Idowu et al., 2009). Endangered, threatened and rare species have successfully been grown and conserved by micropropagation because of high coefficient of multiplication and small demands on number of initial plants and space. In addition, plant tissue culture is considered to be the most efficient technology for crop improvement by the production of somaclonal and gametoclonal variants. The micropropagation technology has a vast potential to produce plants of superior quality, isolation of useful variants in well-adapted high yielding genotypes with better disease resistance and stress tolerance capacities (Brown and Thorpe, 1995). Certain type of callus cultures give rise to clones that have inheritable characteristics different from those of parent plants due to the possibility of occurrence of somaclonal variability (George 1993), which leads to the development of commercially important improved varieties. Commercial production of plants through micropropagation techniques has several advantages over the traditional methods of propagation through seed, cutting, grafting and air-layering etc. It is rapid propagation processes that can lead to the production of plants virus free (Garcia-Gonzales et al., 2010). Coryodalis yanhusuo, an important medicinal plant was propagated by somatic embryogenesis from tuber-derived callus to produce disease free tubers (Sagare et al., 2000). Meristem tip culture of banana plants devoid from banana bunchy top virus (BBTV) and brome mosaic virus (BMV) were produced (El-Dougdoug and El-Shamy, 2011). Higher yields have been obtained by culturing pathogen free germplasm in vitro. Increase in yield up to $150 \%$ of virus-free potatoes was obtained in controlled conditions (Singh, 1992).

Plant tissue culture medium contains all the nutrients required for the normal growth and development of plants. It is mainly composed of macronutrients, micronutrients, vitamins, other organic components, plant growth regulators, carbon source and some gelling agents in case of solid medium. Murashige and Skoog medium (MS medium) is most extensively used for the vegetative propagation of many plant species in vitro. The $\mathrm{pH}$ of the media is also important that affects both the growth of plants and activity of plant growth regulators. It is adjusted to the value between 5.4 - 5.8. Both the solid and liquid medium can be used for culturing. The composition of the medium, particularly the plant hormones and the nitrogen source has profound effects on the response of the initial explant. Plant growth regulators (PGR's) play an essential role in determining the development pathway of plant cells and tissues in culture medium. The auxins, cytokinins and gibberellins are most commonly used plant growth regulators. The type and the concentration of hormones used depend mainly on the species of the plant, the tissue or organ cultured and the objective of the experiment (Ting, 1982). Auxins and cytokinins are most widely used plant growth regulators in plant tissue culture and their amount determined the type of culture established or regenerated. The high concentration of auxins generally favors root formation, whereas the high concentration of cytokinins promotes shoot regeneration. A balance of both auxin and cytokinin leads to the development of mass of undifferentiated cells known as callus. Maximum root induction and proliferation was found in Stevia rebaudiana, when the medium is supplemented with $0.5 \mathrm{mg} / \mathrm{l}$ NAA (Rafiq et al., 2007). Cytokinins generally promote cell division and induce shoot formation and 
axillary shoot proliferation. High cytokinin to auxin ratio promotes shoot proliferation while high auxin to cytokinins ratio results in root formation (Rout, 2004). Shoot initiation and proliferation was found maximum, when the callus of black pepper was shifted to medium supplemented with BA at the concentration of $0.5 \mathrm{mg} / \mathrm{l}$ (Hussain et al., 2011).

\section{Somatic embryogenesis}

Somatic embryogenesis is an in vitro method of plant regeneration widely used as an important biotechnological tool for sustained clonal propagation. It is a process by which somatic cells or tissues develop into differentiated embryos. These somatic embryos can develop into whole plants without undergoing the process of sexual fertilization as done by zygotic embryos. The somatic embryogenesis can be initiated directly from the explants or indirectly by the establishment of mass of unorganized cells named callus. Plant regeneration via somatic embryogenesis occurs by the induction of embryogenic cultures from zygotic seed, leaf or stem segment and further multiplication of embryos. Mature embryos are then cultured for germination and plantlet development, and finally transferred to soil

Somatic embryogenesis has been reported in many plants including trees and ornamental plants of different families. The phenomenon has been observed in some cactus species (Torres-Munoz and Rodriguez-Garay, 1996). There are various factors that affect the induction and development of somatic embryos in cultured cells. A highly efficient protocol has been reported for somatic embryogenesis on grapevine (Jayasankar et al., 1999) that showed higher plant regeneration sufficiently when the tissues were cultured in liquid medium. Plant growth regulators play an important role in the regeneration and proliferation of somatic embryos. Highest efficiency of embryonic callus was induced by culturing nodal stem segments of rose hybrids on medium supplemented with various PGR's alone or in combination (Xiangqian et al., 2002). This embryonic callus showed high germination rate of somatic embryos when grown on abscisic acid (ABA) alone. Somatic embryogenesis is not only a process of regenerating the plants for mass propagation but also regarded as a valuable tool for genetic manipulation. The process can also be used to develop the plants that are resistant to various kinds of stresses (Bouquet and Terregrosa, 2003) and to introduce the genes by genetic transformation (Maynard et al., 1998). A successful protocol has been developed for regeneration of cotton cultivars with resistance to Fusarium and Verticillium wilts (Han et al., 2009).

\section{Organogenesis}

Organogenesis is refered to the production of plant organs i.e. roots, shoots and leaves that may arise directly from the meristem or indirectly from the undifferentiated cell masses (callus). Plant regeneration via organogenesis involves the callus production and differentiation of adventitious meristems into organs by altering the concentration of plant growth hormones in nutrient medium. Skoog and Muller (Skoog and Miller, 1957) were the first who demonstrated that high ratio of cytokinin to auxin stimulated the formation of shoots in tobacco callus while high auxin to cytokinin ratio induced root regeneration.

\section{Slow growth of cultured plants}

Slow growth is usually achieved by reducing the culture temperature, by modifying culture media with supplements of osmotic agents and growth inhibitors, or by removing growth promoters to reduce the cellular metabolism of the material, striving to maximize the time 
between subcultures (Gonçalves and Romano, 2007 and Scherwinski-Pereira et al., 2010). Osmotic regulators, such as sucrose and mannitol, act as growth retardants by causing osmotic stress to the material under conservation. When added to the culture medium, these carbohydrates reduce the hydric potential and restrict the water availability to the explants (Fortes and Scherwinski-Pereira, 2001). Besides temperature and osmotic regulators, growth regulators are also routinely used for in vitro germplasm conservation, with abscisic acid (ABA) being one of the most used.

\section{Cryopreservation of cultured plants}

Cryopreservation is a storage method of plant genetic resources at ultra-low temperature, for example, that of liquid nitrogen (LN; -196 ${ }^{\circ} \mathrm{C}$ ). It is a preservation method that enables plant genetic resources to be conserved safely, and cost-effectively. For successful cryopreservation, it is essential to avoid intracellular freezing and induce the vitrification state of plant cells during cooling in LN. In addition, the cryopreservation method should be a simple protocol for everyone to use easily. Since the 1970's, cryopreservation techniques have been researched using different plant organs, tissues and cells. As a result, different cryopreservation procedures have been developed (for example, slow-prefreezing method, vitrification method, dehydration method).

With the development of these cryopreservation methods, tissues of tropical plants, which have been conventionally thought to be not cryopreserved, also were successfully preserved in LN (Bajaj, 1995; Towill and Bajaj, 2002). Cryobionomics is a new approach to study genetic stability in the cryopreserved plant materials (Harding, 2010). The embryonic tissues can be cryopreserved for future use or for germplasm conservation (Corredoira et al., 2004).

\section{In-situ conservation}

In-situ conservation is the on-site conservation or the conservation of genetic resources in natural populations of plant or animal species, such as forest genetic resources in natural populations of tree species. According to Wikipedia, In-situ conservation involves the following methods:

\section{Biosphere reserves}

Biosphere reserves cover very large areas, often more than $5000 \mathrm{~km}^{2}$. They are used to protect species for a long time.

\section{National parks}

A national park is an area dedicated for the conservation of wildlife along with its environment. It is usually a small reserve covering an area of about 100 to 500 square kilometers. Within biosphere reserves, one or more national parks may also exist.

\section{Wildlife sanctuaries}

A wildlife sanctuary is an area which is reserved for the conservation of animals only.

\section{Biodiversity hotspots}

According to Conservation international, to qualify as a hopspot a region must meet two strict criteria:

- It must contain at least 1,500 species of vascular plants (i.e $0.5 \%$ of the world's total) as endemics,

- It has to have lost at least $70 \%$ of its original habitat. 


\section{Gene sanctuary}

A gene sanctuary is an area where plants are conserved. It includes both biosphere reserves as well as national parks.

\section{Community reserves}

It is the type of protected area introduced in Wildlife Protection Amendment Act 2002 to provide legal support to community or privately owned reserves which cannot be designated as national park or wildlife sanctuary.

\section{Sacred groves}

They are tracts of forest set aside where all the trees and wildlife within are venerated and given total protection.

\section{Ex situ conservation}

Ex situ conservation literally means, "off-site conservation". It is the process of protecting an endangered species, variety or breed, of plant or animal outside its natural habitat. The following method are adopted for Ex situ conservation:

\section{Field gene banks}

It is an assemblage of diverse plant species and their range of genetic diversity in an area. The plant materials are conserved and are available for breeding, reintroduction, research and other purposes. This method is useful for long living perennials trees and shrubs. Botanical gardens often have collections which are effectively field gene banks. These gardens also accommodate some endangered plants.

\section{Seed banks}

Seed banks are the most efficient and effective methods of ex situ conservation for sexually reproducing seeds under long term storage. It is an effective and compact method of storage but is dependent on secure power supply, careful monitoring and testing of seed viability and regeneration in cases where the viability falls below a certain level. There are a number of seed banks in the world with specialisation in the nature of the collections, geographical area, taxonomic groups, wild plants, forestry trees, etc.

\section{In vitro storage}

It refers to the conservation of germplasm through meristem tissues in test tubes. These methods are suited for the long term storage of propagules of species which otherwise cannot be maintained in seed banks.

\section{Uses and values of Plants biodiversity}

Plant species provide a variety of products like food, medicines and raw materials. Some plant extracts are used in the manufacture of glue, soaps, cosmetics, dyes, lubricants and polishes. The plants also provide an important source of renewable energy. The following are the uses of plants species:

\section{Food plants}

One of the most fundamental values of plant biodiversity is in supplying the food for human, domesticated and wild animals and different organisms. Of the estimated 250,000 species of flowering plants at global level, about 3000 are regarded as food source and only 200 species out of these have been domesticated. In the traditional agroecosystems newly domesticated plant types and primitive cultivars emerged from their wild ancestors. Occasional crosses continued to occur between the crops and their wild relatives which increased genetic diversity for further selection and improvement. Many cultivated species may not have survived under domestication without the interchange 
of genes between wild relatives and cultivated crops (Oldfields, 1984).

\section{Crop genetic resources}

The genetically transmitted characters of the crops and wild relatives such as rapid growth and high yields, food quality, stress (biotic and abiotic) tolerance vis-a-vis environmental adaptations are of potential value for hybridization and breeding a desired type of plant. The variations shown by old land races are of great importance in our crop improvement programmes. Genetic erosion or the loss of genetic diversity is an issue of serious concern in relation to sustainable global food security.

\section{Medicinal plants}

Since the dawn of history, man has relied so much on medicinal plants for health and food needs (Nwachukwu et al., 2010). The traditional uses of medicinal plants for curing and preventing illnesses, including the promotion of both physical and spiritual wellbeing among human beings have become paramount (Idu and Onyibe, 2007). Medicinal herbs are consumed all over the world. The use of medicinal herbs to relieve and treat many human diseases is increasing around the world due to their mild features and low side effects (Yap et al., 2010). A World Health Organization (WHO, 2007) survey indicated that about $70-80 \%$ of the world population relies on non-conventional medicine, mainly of herbal sources, in their primary health care. This report revealed that medicinal plants and their trace elements play an important role in the treatment of diseases (Chan, 2003).

\section{Environmental value}

The biological resources make indirect contributions to the welfare and stability of society. Environmental functions support economic activity by recycling important elements like carbon, oxygen and nitrogen and by acting as buffer against excessive variations in weather, climate and other natural events outside the control of human beings. As natural habitat declines, the ecological processes slow down. The rich biodiversity helps in the sustainability/stability for existence, and risk aversion. Therefore ecologist and nature conservationists are much aware of conservation of overall biodiversity for sustainability. Shankar et al., 1995 quotes that "biodiversity changes in rangelands under various kinds of utilization ranging from protection for hay harvest to in situ grazing provides clues to reversing the process of degradation and bringing in the rehabilitation and stability of rangelands productive systems".

In conclusion, the use of plant tissue in conservation of endangered plant species helped in conservation of natural resources and protection against natural disasters that can lead to loss of the species, resulting in reduction of biodiversity and affecting the ecosystem.

\section{References}

Akin-Idowu, P.E., Ibitoye, D.O., Ademoyegun, O.T. (2009). Tissue culture as plant production technique for plant horticultural crop. Afr. J. Biotechnol., 8(16): 3782-3788.

Bajaj, Y.P.S. (1995). Cryopreservation of Plant Germplasm. Biotecnology Agriculture and Forestry, 32 (3):540-574.

Barnosky, A.D., Matzke, N., Tomiya, S., Wogan, G.O.U., Swatzh, B. and Quental, T.B. (2011). Has the Earth's sixth mass extinction already arrived? Nature, 471: $51-57$.

Bouquet, A. and Terregrosa, L. (2003). Micropropagation of grapevine (Vitus spp.). In: Jain SM, Ishii $\mathrm{K}$, editors. Micropropagation of woody trees and fruits. The Netherlands. 75: 319- 352. 
Brown, D.C.W. and Thorpe, T.A. (1995). Crop improvement through tissue culture. World J.Microbiol \& Biotechnol. 11: 409-415.

Chan, K. (2003). Some aspects of toxic contaminants in herbal medicines. Chemosphere, 52:1361-1371.

Corredoira, E., San-Jose, M.C., Ballester, A. and Vieitez, A.M. (2004). Cryopreservation of zygotic embryo axes and somatic embryos of European chestnut. Cryo Lett. 25: 33-42.

Dirzo, R., Young, H.S., Galetti, M., Ceballos, G., Isaac, N.J.B. and Collen, B. (2014). Defaunation in the Anthropocene. Science, 345: 401-406.

El-Dougdoug, K.A. and El-Shamy, M.M. (2011). Management of viral diseases in banana usingcertified and virus tested plant material. Afr. J. Microbiol. Res. 5(32): 5923-5932

Engelman, F. (1991) "In vitro conservation of tropical plant germplasm - a review", Euphytica, 57: 227-243.

Fortes, G.R. de L. and Scherwinski-Pereira, J.E. (2001). Preservação in vitro da batata com ácido acetilsalicílico e duas fontes de carboidrato. Pesquisa Agropecuária Brasileira, 36, 1261-1264.

Garcia-Gonzales, R., Quiroz, K., Carrasco, B. and Caligari, P. (2010). Plant tissue culture: Currentstatus, opportunities and challenges. Cien. Inv. Agr. 37(3): 5-30.

George, E.F. (1993). Plant propagation by Tissue Culture. Eastern Press, Eversley.

Gonçalves, S. and Romano, A. (2007). In vitro minimum growth for conservation of Drosophyllum lusitanicum. Biologia Plantarum, 51(4): 795-798.

Han, G.Y., Wang, X.F., Zhang, G.Y. and Ma, Z.Y. (2009). Somatic embryogenesis and plant regeneration of recalcitrant cottons (Gossypium hirsutum). Afr. J. Biotechnol. 8(3): $432-437$.

Harding, K. (2010). Plant and algal cryopreservation: issues in genetic integrity, concepts in cryobionomics and current applications in cryobiology. Aspac J. Mol. Biol. Biotechnol. 18(1): 151-154.

https://en.wikipedia.org/wiki/In_Situ_Conservatio n_in_India.

Hussain, A., Naz, S., Nazir, H., Shinwari, Z.K. (2011). Tissue culture of black pepper
(Piper nigrum L.) Pakistan. Pak. J. Bot. 43(2): 1069-1078.

Idu, M. and Onyibe, H.I. (2007). Medicinal plants of Edo State, Nigeria. Research Journal of Medicinal Plant, 1(2):32-41.

Jayasankar, S., Gray, D.J. and Litz, R.E. (1999). High-efficiency somatic embryogenesis and plant.

Maynard, C., Xiang, Z., Bickel, S. and Powell, W. (1998). Using genetic engineering to help save American chestnut: a progress report. J. Am Chestnut Found. 12: 40-56.

McCune, J.L., Harrower, W.L., Avery-Gomm, S., Brogan, J.M., Csergo, A.M. and Davidson, L.N.K.(2013). Threats to Canadian species at risk: an analysis of finalized recovery strategies. Biological Conservation, 166: 254-265.

Nwachukwu, C.U., Umeh, C.N., Kalu, I.G., Okere, S. and Nwoko, M.C. (2010). Identification and traditional uses of some common medicinal plants in Ezinihitte Mbaise LGA, Of Imo State, Nigeria. Report and Opinion 2(6): 1 .

Oldfield, M.L. (1984). The value of conserving genetic resources. USDl, National Park Service, Washington D.C.

Prugh, L.R., Sinclair, A.R.E, Hodges, K.E., Jacob, A.L. and Wilcove, D.S. (2010). Reducing threats to species: threat reversibility and links to industry. Conservation Letters, 3: 267-276.

Rafiq, M., Dahot, M.U., Mangrio, S.M., Naqvi, H.A. and Qarshi, I.A. (2007). In vitro clonal propagation and biochemical analysis of field established Stevia rebaudiana Bertoni. Pak. J. Bot. 39(7): 2467-2474.

regeneration from suspension cultures of grapevine. Plant Cell Rep. 18: 533-537.

Rout, G.R. (2004). Effect of cytokinins and auxin on micropropagation of Clitoria ternatea $L$. Biol. Lett. 41(1): 21-26.

Sagare, A.P., Lee, Y.L., Lin, T.C., Chen, C.C.and Tsay, H.S. (2000). Cytokinin-induced somatic embryogenesis and plant regeneration in Coryodalis yanhusuo (Fumariaceae). a medicinal plant. Plant Sci. 160: 139-147.

Scherwinski-Pereira, J.E., Costa, F.H.S., Camillo, J., Silva, D.B., Alves, R.B.N., Vieira, R.F. (2010). Tissue culture storage of Brazilian 
medicinal plants germplasm. Acta Horticulturae, p. 211-214.

Scherwinski-Pereira, J.E., Costa, F.H.S., Camillo, J., Silva, D.B., Alves, R.B.N., Vieira, R.F. (2010). Tissue culture storage of Brazilian medicinal plants germplasm. Acta Horticulturae, p. 211-214.

Sengar, R.S., Chaudhary, R., Tyagi, S.K. (2010). Present status and scope of floriculture developed through different biological tools. Res J. of Agri. Sci., 1(4): 306-314.

Shankar, V., Singh, J.P. and Anjali, K. (1995). Conservation of biodiversity on tropical rangelands of India. Proc. National Symposium on Agriculture and Environment, pp. 32 - 34.

Singh, R.B. (1992). Current status and future prospects of plant biotechnologies indeveloping countries in Asia. In: Sasson A, Costarini, editors. Plant Biotechnologies for Developing Countries. London: 141162.

Skoog, F. and Miller, C.O. (1957). Chemical regulation of growth and organ formation in plant tissue cultures in vitro. Symp. Soc. Exp. Biol. 11: 118-131.

Thomas, W.H. (2003). One last chance: tapping indigenous knowledge to produce sustainable conservation policies. Futures 35: 989-998.

Thorpe, T. (2007). History of plant tissue culture. J. Mol. Microbial Biotechnol. 37: 169-180.

Ting, I.P. (1982). Plant physiology. AddisonWesleyn Reading, Massachusetts. 642.

Torres-Munoz, L. and Rodriguez-Garay, B.
(1996). Somatic embryogenesis in the threatened cactus Turbinicarpus psudomacrochele (Buxbaum \& Backerberg). J. PACD. 1: 36-38.

Towill, L.E. and Bajaj, Y.P.S. (2002). Cryopreservation of Plant Germplasm. Biotecnology Agriculture and Forestry, 50 (3): 540-676.

Tyagi, R.K., Agrawal, A., Mahalakshmi, C., Hussain, Z., Tyagi, H. (2007). Low-cost media for in vitro conservation of turmeric (Curcuma longa L.) and genetic stability assessment using RAPD markers. In-Vitro Cell. Develop. Biol. Plant, 43: 51-58.

Usher, P.J. (2000). Traditional ecological knowledge in environmental assessment and management. Arctic, 53(2): 183-193.

Venter, O., Brodeur, N.N., Nemiroff, L., Belland, B., Dolinsek, I.J. and Grant, J.W.A. (2006). Threats to endangered species in Canada. Bioscience, 56: 903-910.

WHO, (2007). Guidelines for assessing quality of herbal medicine. World Health Organization Geneva.

Xiangqian, L.I., Krasnyanski, F.S., Schuyler, S.K. (2002). Somatic embryogenesis, secondary somatic embryogenesis and shoot organogenesis in Rosa. Plant Physiol. 159: 313-319.

Yap, C.K., Mohd-Fitrim, M.R., Mazyhar, Y. and Tan, S.G. (2010). Effects of metal contaminated soils on the accumulation of heavy metals in different parts of Centella asiatica: A laboratory study. Sains Malaysiana, 39(3):347-352.

\section{How to cite this article:}

Ojo Michael Oseni, Veena Pande and Tapan Kumar Nailwal. 2018. A Review on Plant Tissue Culture, A Technique for Propagation and Conservation of Endangered Plant Species. Int.J.Curr.Microbiol.App.Sci. 7(07): 3778-3786. doi: https://doi.org/10.20546/ijcmas.2018.707.438 